\title{
Trust, Literasi Media, Kepribadian HEXACO dan Husnudzon Terhadap Kecenderungan Menggunakan Media Sosial
}

\author{
Desri Rodhiatun Mardhiah \& Ikhwan Lutfi, M.Psi \\ Fakultas Psikologi \\ Universitas Islam Negeri Syarif Hidayatullah Jakarta \\ Snoopy.murfi@mhs.uinjkt.ac.id, Ikhwan.lutfi@uinjkt.ac.id
}

\begin{abstract}
This study was conducted to determine the significance of the influence of trust information, media literacy, HEXACO personality and Husnudzon towards the tendency of using social media for seeking information at student college. The subject of this research was 280 students taken by probability sampling technique, namely cluster sampling. CFA (Confirmatory Factor Analysis) was used to test the validity of measuring instruments and logistic regression analysis is used to test the research hypothesis. The results showed that there was a significant joint effect of trust, media literacy, HEXACO's personality and Husnudzon towards the tendency of using social media for seeking information. Hypothesis test results show that six variables namely trust, structure of media literacy knowledge, personal media literacy locus, extraversion personality type, Husnudzon towards God, and Husnudzon towards others have a significant influence on the tendency of using social media for seeking information. Meanwhile, media literacy competencies, personality types; honesty-humility, emotionality, agreeableness, conscientiousness, and openness to experience do not have a significant influence on the tendency of using social media for seeking information. The results also show the proportion of variance from the tendency of using social media for seeking information explained by all independent variables is $18.0 \%$ while the remaining $82.0 \%$ is influenced by other variables outside of this study.
\end{abstract}

Keywords: Social Media, Trust, Media Literacy, Personality, Husnudzon

\begin{abstract}
Abstrak
Penelitian ini dilakukan untuk mengetahui signifikansi pengaruh trust informasi, literasi media, kepribadian HEXACO dan husnudzon terhadap kecenderungan menggunakan media sosial untuk mencari informasi pada mahasiswa. Subjek penelitian ini berjumlah 280 mahasiswa yang diambil dengan teknik probability sampling yaitu cluster sampling. CFA (Confirmatory Factor Analysis) digunakan untuk menguji validitas alat ukur dan logistic regression analysis digunakan untuk menguji hipotesis penelitian. Hasil penelitian menunjukkan bahwa ada pengaruh secara bersama-
\end{abstract}


sama yang signifikan dari trust, literasi media, kepribadian HEXACO dan husnudzon terhadap kecenderungan menggunakan media sosial untuk mencari informasi. Hasil uji hipotesis menunjukkan bahwa enam variabel yaitu trust, struktur pengetahuan literasi media, lokus personal literasi media, tipe kepribadian extraversion,husnudzon terhadap Allah, dan husnudzon terhadap sesamamemiliki pengaruh yang signifikan terhadap kecenderungan menggunakan media sosial untuk mencari informasi. Sementara itu, kompetensi-keterampilan literasi media, tipe kepribadian; honesty-humility,emotionality, agreeableness, conscientiousness, dan openness to experience tidak memiliki pengaruh yang signifikan terhadap kecenderungan menggunakan media sosial untuk mencari informasi. Hasil penelitian juga menunjukkan proporsi varians dari kecenderungan menggunakan media sosial untuk mencari informasi yang dijelaskan oleh seluruh variabel independen adalah $18.0 \%$ sedangkan $82.0 \%$ sisanya dipengaruhi oleh variabel lain diluar penelitian ini.

Keywords: Media Sosial, Kepercayaan, Literasi Media, Kepribadian, Husnudzon

\section{Pendahuluan}

Kecenderungan menggunakan media sosial untuk mencari informasi merupakan hal yang tidak asing lagi dalam kehidupan manusia. Zuniga, Jung, dan Valenzuela (2012) mendefinisikan Kecenderungan menggunakan media sosial untuk mencari informasi sebagai motivasi individu untuk tetap terinformasi dan mendapatkan update informasi terkini melalui penggunaan media sosial. Informasi tersebut adalah informasi mengenai kejadian publik yang dikomunikasikan melalui media sosial, seperti informasi ketika individu melamar kerja di suatu perusahaan, berdiskusi tentang isu politik, dan berbagi tautan ke story media sosial melalui informasi media mainstream.

Saat ini media sosial dianggap sebagai salah satu teknologi yang penggunaannya meningkat sebagai sumber untuk mendapatkan informasi. (Pepitone; Westerman, 2013). Media sosial merupakan bagian internet yang memberikan kekuasaan individu untuk menginformasikan gagasannya kepada orang lain, baik secara interpersonal maupun dalam jumlah yang banyak (Winkelmann, 2012). Berdasarkan survei statistik Brandwatch tahun 2015 bahwa dalam setiap hari ada 1 juta pengguna media sosial yang setara dengan 12 orang perdetik. Dari hasil survey yang dilakukan oleh Asosiasi Penyelenggara Jasa Internet Indonesia, di Indonesia sendiri terhitung 132,7 juta pengguna internet dan 129,2 juta diantaranya menggunakan internet untuk membuka mediasosial (APJII, 2016; Mahardika, 2017).

Menurut Katz dan Gurevitch (1974) individu menggunakan media sosial untuk mengamati peristiwa terkini, hubungan pertemanan, hiburan, dan sebagai identitas sosial. Penelitian 
sebelumnya mengungkapkan bahwa individu yang sering mengkonsumsi informasi di media sosial, cenderung dapat meningkatkan ketertarikan pada partisipasi politik, pengetahuan tentang masalah publik, dan gerakan sosial. Menurut Susanto (2011) terdapat beberapa masalah dalam mendapatkan informasi di media sosial, yaitu berupa masalah sumber yang patut dipercaya

Era banjir informasi di media sosial saat ini sering disebut sebagai era ketidakpastian informasi. Informasi mengalir deras setiap hari, jam, menit dan detik. Meluapnya informasi saat ini, melebihi kemampuan individu untuk menyerapnya. Media-media sosial memberitakan informasi atas sebuah peristiwa dengan cepat. Segala informasi tersebut saat ini masuk kedalam ruang-ruang personal ponsel dan laptop, menembus ke dalam pesan broadcast di media sosial whatsapp atau line individu. Ironisnya, Individu sering kali tidak tahu apakah informasi yang datang tersebut benar atau salah. Meluapnya informasi di media sosial berdampak pada informasi yang bukan saja tidak sempat diolah, namun juga sama sekali tidak mungkin dipakai (kompas.com, 2018).

Suatu media online di Indonesia setidaknya mengunggah 400 hingga 2.500 berita per hari. Meski jumlah berita dalam satu hari mengalir deras, rata-rata pengguna internet di Indonesia tidak sampai membaca 10 berita informasi. Menurut Bill Kovach dan Tom Rosenstiel (kritikus media informasi digital), ketika informasi melimpah banyak, kebenaran justru menjadi suatu hal yang semakin tidak pasti. Media tradisional, yang terlebih dahulu dianggap memiliki kredibilitas, saat ini mengamplifikasi ketidakpastian untuk kepentingan komoditas informasi. Informasi yang dipersepsikan sebagai sumber pengetahuan mulai dikhawatirkan sebagai sumber kecemasan. Informasi malah menjadi sumber kecemasan baru (kompas.com, 2018).

Salah satu dampak negatif dari penggunaan media sosial adalah berita bohong. Berita bohong atau sering disebut hoax kini tengah menjadi persoalan yang cukup serius di Indonesia. Pasalnya, hoax menjadi salah satu pemicu fenomena putusnya pertemanan, gesekan, dan permusuhan. Informasi yang bersifat hoax menyebar dengan cepat baik melalui saluran media sosial maupun grup di aplikasi chatting, misalnya WhatsApp, BlackBerry Messenger, dan masih banyak lagi (kompas.com, 2017).

Permasalahan hoax sudah mencapai tingkat nasional. Presiden Joko Widodo meminta adanya tindakan tegas terhadap situs-situs berita yang menyebar kebohongan, dengan judul provokatif, dan sumber yang tidak jelas. Menkominfo pun melakukan pemblokiran pada beberapa situs yang dinilai hoax dan radikal. Sedangkan Dewan Pers melakukan pembenahan Undang-undang ITE terhadap media-media online. (Mahardika, 2017).

Salah satu contoh hoax yang marak di Indonesia adalah bentuk fenomena web phishing pada aplikasi media sosial whatsapp. Web phishing adalah suatu metode untuk melakukan penipuan dengan mengelabui pengguna media sosial dengan maksud untuk mencuri akun pengguna media 
sosial. Web phishing pada aplikasi media sosial whatsapp dilakukan dengan mengirimkan pesan kupon hadiah atau informasi lamaran kerja melalui suatu tautan, dengan modus menggandakan nomor whatsapp, Pin BB, Pin M-Banking; BCA, BRI, BNI, dll. Pembuatan berita web phishing identik dengan penyebaran hoax. Fenomena ini dinilai merugikan pengguna media sosial, karena data pribadi mereka dapat disalah gunakan oleh pihak yang tidak bertanggung jawab (idcloudhost.com, 2018). Berdasarkan dampak positif dan negatif kecenderungan menggunakan media sosial untuk mencari informasi pada individu, maka peneliti merasa penting untuk mencari tahu apa saja faktor yang dapat mempengaruhi kecenderungan menggunakan media sosial untuk mencari informasi.

Salah satu faktor yang mempengaruhi kecenderungan menggunakan media sosial untuk mencari informasi adalah trust. Trust informasi di media sosial dapat didefinisikan sebagai kepercayaan subyektif individu terhadap informasi di media. Kepercayaan dimana informasi di media sudah memiliki kredibilitas, wartawan sudah bekerja sesuai dengan standar profesional, dan bahwa informasi di media dapat membantu menyelesaikan masalah individu (Tsfati dan Cappella, 2003). Pada media sosial, perilaku trust dapat membantu individu dalam mengatasi persepsi ketidakpastian dan resiko dalam penggunaan aplikasi media sosial. Persepsi tersebut sangat kuat ketika berinteraksi dengan menggunakan aplikasi yang belum diketahui sebelumnya. Dengan demikian, trust sangat penting dalam mendapatkan informasi di media sosial (McKnight dkk, 2002).

Penelitian Vraga, Tully dan Rojas (2009) menyatakan semakin individu paham dan sering menggunakan suatu aplikasi media sosial, maka semakin meningkatkan kepercayaan individu pada suatu aplikasi media sosial. Dengan demikian individu yang paham dan sering menggunakan suatu aplikasi media sosial, maka jenis konten apapun yang ada pada aplikasi tersebut, akan individu mempercayai. Meskipun konten tersebut adalah berita bohong, individu akan tetap percaya, karena aplikasi media sosial tersebut sudah dipercayai.

Selain trust, literasi media juga merupakan salah satu faktor yang dapat mempengaruhi penggunaan media sosial. Literasi media dapat didefinisikan sebagai perspektif di mana individu dapat secara aktif menunjukkan kemampuannya kepada media untuk menginterpretasikan makna dari pesan informasi yang ditemukan. Sederhananya, informasi tidak sertamerta diterima oleh masyarakat, melainkan masing-masing individu mampu menyaring berita mana yang harus dibagikan dan berita mana yang harus disimpan sendiri, sebagai upaya penanganan isu hoax yang semakin gencar di Indonesia (tirto.id, 2017).

Pada penelitian Wegmann, dkk (2015) literasi media memberikan pengaruh yang signifikan terhadap kecenderungan menggunakan media sosial untuk mencari informasi. Literasi media dapat 
mengurangi penggunaan media sosial individu secara negatif, individu akan lebih menggunakan media sosial untuk mencari informasi secara baik. Semakin individu dapat mengontrol diri atau memiliki literasi media yang baik, maka semakin individu tersebut menggunakan media sosial utuk mencari informasi yang benar.

Selain trust dan literasi media, kepribadian juga merupakan salah satu faktor yang dapat mempengaruhi kecenderungan menggunakan media sosial untuk mencari informasi. Penelitian sebelumnya yang dilakukan oleh Hamburger dan Vinitzky (2010) mengemukakan bahwa kepribadian dapat mempengaruhi kecenderungan menggunakan media sosial untuk mencari informasi. Menurut Hamburger (2005) kepribadian adalah faktor utama dalam memahami perilaku individu di media sosial. Media sosial pada dasarnya adalah interaksi manusia, maka kita tidak dapat memahami cara kerja media sosial tanpa memahami kepribadian individu yang menggunakannya.

Pada penelitian ini, peneliti mengadopsi model kepribadian HEXACO (Ashton dan Lee, 2007), karena model HEXACO merupakan model kepribadian yang mencerminkan kemajuan terbaru dalam psikologi kepribadian (Fajar dan Lutfi, 2017). Model kepribadian HEXACO merupakan pengembangan dari model big five yang terdiri dari enam dimensi, dimana model kepribadian ini dapat menjelaskan fenomena kepribadian yang tidak dijelaskan dalam konsep big five personality. Ashton dan Lee (2007) membuat model kepribadian HEXACO yang terdiri dari enam domain. Kepribadian dengan model HEXACO mirip dengan kepribadian big five, karena keduanya memiliki tiga dimensi yang serupa yaitu extraversion, agreeableness, dan openness to experience. Perbedaan antara HEXACO dengan big five adalah adanya penambahan honesty-humility serta diubahnya dimensi neuroticism menjadi emotionality pada model HEXACO personality (Ashton dan Lee, 2007). Kata HEXACO yang digunakan oleh Ashton dan Lee pada model yang dikembangkannya merupakan kata yang diambil dari bahasa Yunani, Hexa yang berarti enam dan juga merupakan perwakilan dari masing-masing domain atau dimensi yaitu: $\mathrm{H}$ adalah Honesty-Humility, $\mathrm{E}$ adalah Emosionality, X adalah Extraversion, A adalah Agreeableness, $\mathrm{C}$ adalah Conscientiousness, dan $\mathrm{O}$ adalah Openness to Experience (Ashton, 2013).

Selain trust, literasi media dan kepribadian, faktor lain yang mempengaruhi kecenderungan menggunakan media sosial untuk mencari informasi adalah husnudzon atau prasangka baik. Rusydi (2012) mengemukakan bahwa husnudzon adalah suatu sifat berprasangka baik yang terlahir dari hati yang tentram untuk menerima ketetapan dari Allah sehingga akan dijauhkan dari perasaanperasaan gelisah, takut, serta cemas. Menurut tokoh islam Ibnu Taimiyah, diantara tanda-tanda orang husnudzon itu dapat dilihat secara nyata bahwa ia taat kepada Allah SWT. Seberapa tinggi 
ketaatannya itulah ukuran husnudzon orang yang berhusnudzon kepada yang ditaatinya (Rusydi, 2012).

Pada penelitian sebelumnya, mengungkapkan bahwa suatu prasangka yang muncul akibat minimnya individu dalam mendapatkan informasi, dapat mempengaruhi sikap individu. Semakin individu memiliki prasangka yang baik maka semakin individu tersebut mencari informasi yang benar di media sosial (Dhont, 2011). Dalam penelitian yang dilakukan oleh Rauch (2013) menyebutkan bahwa prasangka memberikan pengaruh yang signifikan terhadap kecenderungan menggunakan media sosial untuk mencari informasi, terutama informasi dengan konten SARA. Semakin individu dengan frekuensi pencarian informasi rendah dan cenderung menggunakan media sosial untuk mencari informasi SARA, maka semakin individu memiliki prasangka negatif dan setuju dengan informasi SARA, individu cenderung menunjukkan pola diskriminasi. Sebaliknya, semakin individu memiliki frekuensi yang tinggi dalam pencarian informasi di media sosial, maka semakin individu menolak informasi negatif, khususnya informasi dengan konten SARA. Individu lebih cenderung pada pesan egaliter, atau kesetaraan.

Berdasarkan fenomena dan faktor yang telah dijelaskan, peneliti tertarik untuk melakukan penelitian lebih lanjut, menguji pengaruh trust, literasi media, tipe keribadian (berdasarkan model HEXACO) dan husnudzon terhadap Kecenderungan menggunakan media sosial untuk mencari informasi pada mahasiswa.

\section{Landasan Teori}

\section{Materials Kecenderungan Menggunakan Media Sosial untuk Mencari Informasi}

Zu'niga, Jung, dan Valenzuela (2012) menyatakan bahwa kecenderungan menggunakan media sosial untuk mencari informasi didefinisikan sebagai motivasi individu untuk tetap terinformasi dan mendapatkan update informasi terkini melalui penggunaan media sosial. Informasi tersebut adalah informasi mengenai kejadian publik yang dikomunikasikan melalui media sosial, seperti informasi ketika individu melamar kerja di suatu perusahaan, berdiskusi tentang isu politik, dan berbagi tautan ke story media sosial melalui informasi media mainstream. Zu'niga dkk (2012) juga menjelaskan bahwa kecenderungan menggunakan media sosial untuk mencari informasi terbagi atas dua dimensi, yaitu:

\section{a. Stay informed}

Indidvidu menggunakan media sosial untuk tetap mendapatkan informasi tentang peristiwa terkini dan kejadian publik, dan individu menggunakan media sosial untuk tetap mendapatkan informasi tentang masyarakat lokal.

\section{b. Get news}


Individu menggunakan media sosial untuk mendapatkan update informasi terkini dari berita utama media mainstream, dan untuk mendapatkan informasi tentang update hal terkini melalui publik.

\section{Trust Informasi}

Penelitian ini menggunakan teori strategi coping dari Tsfati dan Cappella (2003) yang didefinisikan sebagai kepercayaan subyektif individu terhadap informasi di media. Kepercayaan dimana informasi di media memiliki kredibilitas, wartawan bekerja sesuai dengan standar profesional mereka, dan bahwa informasi di media dapat membantu menyelesaikan masalah individu. Berdasarkan definisi diatas Tsfati dan Capella (2003) membagi strategi trust informasi menjadi 4 dimensi, yaitu:

a. Adil

Definisi dimensi adil pada trust adalah persepsi dimana wartawan atau pers sudah adil dan obyektif dalam laporan informasi, persepsi dimana pers sudah adil dalam menceritakan keseluruhan informasi, dan persepsi dimana pers tidak akan mengorbankan akurasi dan penghargaan untuk keuntungan pribadi dan komersial.

b. Akurat

Menurut Mutz (1998), karena media sosial berurusan dengan hal yang tidak bersifat pribadi, maka individu belum menemukan kepastian hal akurat pada konten media informasi. Individu masih memiliki kesulitan dalam memverifikasi laporan media dengan sumber non media.

c. Menceritakan keseluruhan informasi

Pada dimensi ini berisi persepsi bahwa pers sudah adil dalam menceritakan keseluruhan informasi. Trust berkaitan dengan persepsi subjektif dan pribadi. Trust juga menampakkan kestabilan sifat pada individu, terlepas dari kualitas objektif dari suatu sumber informasi (Berlo, Lemert, dan Mertz, 1969). Teks media tertentu sering dipersepsikan sebagai hal yang tidak adil dan memiliki kecenderungan pada pandangan politik kelompok tertentu, dan hal tersebut memang sudah didukung penelitian sebelumnya, bahwa kepercayaan media memiliki korelasi dengan sikap politik kelompok tertentu (Tsfati, 2003).

\section{d. Dapat dipercaya}

Suatu media seharusnya memiliki penilaian dari individu terhadap jurnalis, apakah jurnalis sudah dapat dipercaya, jujur dalam suatu informasi atau apakah jurnalis hanya termotivasi oleh ambisi pribadi dan kompetensi kelembagaan. Individu cenderung memiliki harapan yang mengarah pada keuntungan daripada kerugian. Trust terkait dengan harapan agar orang lain (individu) akan mendapat manfaat dari karya jurnalis dalam hal ini adalah manfaat informasi. 


\section{Literasi Media}

Menurut Potter (2004), literasi media merupakan sebuah perspektif di mana kita dapat secara aktif menunjukkan kemampuan kita kepada media untuk menginterpretasikan makna dari pesan yang kita temui. Maksl, Ashley dan Craft (2015) juga menjelaskan bahwa literasi media terdiri dari tiga dimensi, yaitu:

\section{Struktur Pengetahuan}

Landasan membangun literasi media adalah seperangkat lima struktur pengetahuan dasar yang kuat. Struktur pengetahuan adalah struktur pengetahuan dasar dalam literasi media, yang terdiri dari: efek media, konten media, industri media, dunia nyata, dan individu. Melalui pengetahuan dalam lima struktur dasar literasi media, individu akan lebih sadar selama tugas pemrosesan informasi, individu akan mampu membuat keputusan yang lebih baik tentang pencarian informasi, mengelola informasi, dan membangun makna dari informasi yang bermanfaat.

\section{Lokus Personal}

Lokus personal adalah hal-hal yang mengatur tugas-tugas pemprosesan informasi dalam literasi media. Lokus personal terdiri dari tujuan dan motivasi. Sasarannya adalah membentuk tugas pemprosesan informasi dengan menentukan informasi dimana saja yang difilter lalu digunakan, dan informasi mana saja yang difilter lalu diabaikan. Lokus personal dapat membentuk konstruksi makna informasi yang sesuai. Semakin individu sadar dalam membuat keputusan, maka semakin individu tersebut dapat mengendalikan pemprosesan informasi. Semakin individu memperhatikan secara sadar lokusnya, maka individu semakin mengendalikan proses perolehan dan penggunaan informasi.Semakin individu mempergunakan lokus personalnya, maka semakin tinggi individu meningkatkan literasi media.

\section{Kompetensi-Keterampilan}

Setelah lokus personal menyediakan energi dan rencana, tools atau alat diperlukan untuk melaksanakan rencana tersebut. Kompetensi-ketrampilan adalah alat yang memungkinkan individu untuk mengakses asosiasi mental sederhana dalam lietarsi media. Memiliki kompetensi tidak membuat satu individu memiliki literasi media yang baik, tetapi kekurangan kompetensi ini mencegah individu untuk memiliki literasi media yang baik, karena hal tersebut dapat mencegah individu mengakses jenis informasi tertentu.

\section{Kepribadian HEXACO}

Ashton (2013) menyatakan bahwa kepribadian mengacu pada perbedaan antar individu pada kecenderungan yang khas dalam berperilaku, berpikir, atau merasa pada beberapa hal konseptual terkait, di berbagai situasi yang relevan dan di beberapa periode waktu yang cukup lama. Ashton 
dan Lee (2013) menyatakan bahwa terdapat enam domain kepribadian pada individu, ke-enam domain yang dimaksud yaitu :

\section{Honesty-Humility $(H)$}

Domain ini menunjukkan kejujuran dan kerendahan hati individu. Dalam melihat honesty-humility pada individu digambarkan dalam empat hal. Keempat hal tersebut adalah Sincerity (ketulusan) menilai kecenderungan untuk menjadi tulus dalam hubungan interpersonal, Fairness (keadilan) menilai kecenderungan untuk menghindari penipuan, Greed (keserakahan) menilai kecenderungan untuk tidak tertarik dalam memiliki kekayaan. Modesty (kesederhanaan) menilai kecenderungan untuk menjadi sederhana (Lee danAshton, 2004).

\section{Emotionality $(E)$}

Domain ini melihat pengalaman emosional individu dalam kehidupannya. Dalam melihat emotionality pada individu digambarkan dalam empat bagian. Keempat bagian tersebut adala Fearfulness (rasa takut) menilai kecenderungan untuk mengalami rasa takut, Anxiety (kecemasan) menilai kecenderungan untuk khawatir di berbagai hal, Dependence (ketergantungan) menilai kebutuhan dukungan secara emosional daro orang lain, Sentimentality (sentimental) menilai kecenderungan untuk merasakan emosi yang kuat dengan orang lain (Lee dan Ashton, 2004).

\section{Extraversion $(X)$}

Domain ini melihat kedalam diri individu dalam menjalankan kehidupannya. Dalam melihat extraversion pada individu digambarkan dalam empat bagian. Keempat bagian tersebut adalah Expressiveness (ekspresi) menilai kecenderungan kegembiraan dan drama dalam kehidupan interpersonal, Social Boldness (keberanian sosial) menilai kenyamanan individu atau Trust diri saat berada dalam berbagai situasi sosial, Sociability (keramahan) menilai kenyamanan dalam berkomunikasi, berinteraksi sosial, Liveliness (keaktifan) menilai keantusiasan dan energi yang dimiliki individu (Lee dan Ashton, 2004).

\section{Agreeableness (A)}

Agreebleness digunakan untuk melihat interaksi individu dengan orang lain. Individu dibedakan menjadi empat bagian dalam agreebleness yaitu, forgiveness (memafkaan) menilai kesedian untuk percaya pada individu lain yang pernah melakukan kesalahan, gentleness (kelembutan) menilai kemudahan dalam menyelesaikan masalah dengan orang lain, flexibility (fleksibel) menilai kesediaan bekerjasama dengan orang lain, dan patience (kesabaran) menilai kecenderungan untuk tenang dan tidak mudah marah (Ashton dan Lee, 2013).

\section{Conscientiousness $(C)$}

Domain ini digunakan untuk melihat individu dalam melakukan kegiatan dan tugas sehari-hari. Gambaran conscientiousness pada individu, dapat dilihat dari empat bagian yaitu, organization 
(organisasi) menilai kecenderungan untuk mencari keteraturan, diligence (ketekunan) menilai kerja keras, perfectionism (perfeksionis) penilaian dalam ketelitian dan kepedulian terhadap hal yang detail, prudence (kebijaksanaan) penilaian dalam kecenderungan berbicara dengan hati-hati (Ashton dan Lee, 2013).

\section{Openness to Experience $(O)$}

Domain ini melihat keterbukaan individu pada pengalaman. Pada Opennes to Experience, dalam menggambarkannya terdapat empat bagian yaitu, aesthetic (keindahan) menilai penghayatan seseorang dalam menikmati keindahan seni dan alam, inquisitiveness (rasa ingin tahu) menilai keingintahuan yang dimiliki mengenai alam dan manusia, creativity (kreativitas) menilai preferensi seseorang dalam inovasi dan eksperimen, dan unconventionality (tidak konvensional) menilai kecenderungan dalam menerima ide yang tidak biasa (Ashton dan Lee, 2013).

\section{Husnudzon}

Husnudzon adalah suatu sifat berprasangka baik yang terlahir dari hati yang tentram untuk menerima ketetapan dari Allah sehingga akan dijauhkan dari perasaan-perasaan gelisah, takut, sertacemas (Rusydi, 2012). Dimensi husnudzon menurut Rusydi (2012) antara lain adalah:

1. Husnudzon terhadap Allah

Husnudzon kepada Allah SWT adalah berprasangka baik terhadap Allah yaitu mempercayai Allah dan hanya kepada-Nya tempat mengadukan segala persoalan dan seluruh ridha kepada qadha dan qadar-Nya, serta batin yang selalu tenang dalam menghadapi segala sesuatu yang terjadi atau sesuatu yang dicita-citakan tidak sesuai dengan kehendak Allah.

\section{Husnudzon terhadap sesama}

Baik sangka kepada sesama manusia adalah dengan menganggap atau berpikir bahwa segala yang dilakukan orang lain itu adalah hal baik. Dalam hal ini berprasangka baik pada sesama manusia, adalah mengenai sikap yang terkait dengan sikap tajassus (mencari kejelekan orang dan lain), tahassus (mendengarkan kejelekan orang lain) benci, dan iri (Rusydi, 2012).

\section{Metode}

\section{Populasi, Sampel dan Teknik Sampling}

Populasi pada penelitian ini berjumlah 33.420 individu, yang merupakan mahasiswa aktif Universitas Islam Negeri Syarif Hidayatullah Jakarta. Sampel dari penelitian ini berjumlah 280 individu. Teknik sampling yang digunakan adalah convenience sampling, yang berarti kemungkinan terpilihnya dari setiap responden anggota populasi tidak diketahui. 


\section{Instrumen Penelitian}

1. Kecenderungan Menggunakan Media Sosial untuk Mencari Informasi

Kecenderungan menggunakan media sosial untuk mencari informasi diukur menggunakan social network site for news scale yang dikembangkan oleh Zuniga, Jung dan Valenzuela (2012). Skala ini memiliki dua dimensi, yaitu stay inform dan get news. Pada tiap-tiap dimensi terdiri atas 2 item. Dimana masing-masing item memiliki empat pilihan jawaban, yaitu sangat setuju, setuju, tidak setuju, dan sangat tidak setuju.

\section{Trust Informasi}

Trust informasi diukur menggunakan news media credibility scale yang dikembangkan oleh Tsafati dan Capella (2003). Skala ini terdiri atas 4 dimensi, yaitu adil, akurat, menceritakan keseluruhan informasi, dan dapat dipercaya. Terdapat 8 item pada skala ini dengan empat pilihan respon, yaitu yaitu sangat setuju, setuju, tidak setuju, dan sangat tidak setuju.

\section{Literasi Media}

Literasi media diukur menggunakan cognitive model of media literacy berdasarkan teori Potter (2004). Skala ini terdiri atas tiga dimensi, yaitu struktur pengetahuan, lokus personal, kompetensi dan keterampilan. Terdapat 28 item pada skala ini dengan empat pilihan respon, yaitu sangat tidak setuju, tidak setuju, setuju dan sangat setuju.

\section{Kepribadian HEXACO}

Kepribadian HEXACO diukur menggunakan brief HEXACO inventoryscale yang dikembangkan oleh Vries (2013). Skala ini terdiri atas 6 dimensi, yaitu Honesty-Humility (H), Emotionality (E), Extraversion (X), Agreeableness (A), Conscientiousness (C), Openness to Experience (O). Terdapat 24 item pada skala ini dengan empat pilihan respon, yaitu yaitu sangat setuju, setuju, tidak setuju, dan sangat tidak setuju.

\section{Husnudzon}

Husnudzon diukur menggunakan skala yang dibuat oleh Rusydi (2012). Skala ini terdiri atas dua dimensi, yaitu husnudzon terhadap Allah dan husnudzon terhadap sesama. Terdapat 24 item pada skala ini dengan empat pilihan respon, yaitu sangat tidak setuju, tidak setuju, setuju dan sangat setuju.

Prosedur 
Peneliti mencari inidividu yang sesuai dengan kriteria, yaitu mahasiswa aktif Universitas Islam Negeri Hidayatullah Jakarta. Mahasiwa yang sesuai kriteria dan menandatangani inform consent baru diperbolehkan untuk mengerjakan kuesioner.

\section{Hasil}

Analisis regresi menghasilkan nilai $R$-Square sebesar 0,180. Dengan demikian besarnya pengaruh variable (trust informasi, struktur pengetahuan, lokus personal, kompetensi-keterampilan, extraversion, conscientiousness, openness to experience, husnudzon terhadap Allah, dan husnudzon terhadap sesama) terhadap dependent variable (kecenderungan menggunakan media sosial untuk mencari informasi) ialah sebesar 18,0\%. Dapat dilihat pada tabel 1 berikut:

Tabel 1

R Square

\begin{tabular}{ccccc}
\hline Model & R & R Square & Adjusted R Square & Std. Erros of the Estimete \\
\hline 1 & $.425^{\mathrm{a}}$ & .180 & .153 & 7.97426 \\
\hline
\end{tabular}

Selanjutnya, pada pengujian uji $\mathrm{F}$ ditemukan bahwa taraf signifikansi (p) pada penelitian ini ialah sebesar 0,000. Dapat diartikan bahwa terdapat pengaruh yang signifikan dari trust informasi, literasi media (struktur pengetahuan, lokus personal, dan kompetensi-keterampilan), kepribadian HEXACO (extraversion, conscientiousness, dan openness to experience)dan husnudzon (husnudzon terhadap Allah, husnudzon terhadap sesama) terhadap kecenderungan menggunakan media sosial untuk mencari informasi. Adapun hasil uji F dapat dilihat pada tabel 2 berikut:

\section{Tabel 2}

\begin{tabular}{clrrrrr}
\multicolumn{1}{c}{ Anova } & \multicolumn{1}{c}{ Sum of Squares } & Df & Mean Square & \multicolumn{1}{c}{ F } & Sig. \\
\hline Model & & 3746.759 & 9 & 416.307 & 6.547 & $.000^{\mathrm{b}}$ \\
\hline 1 & Regression & 17041.796 & 268 & 63.589 & & \\
& Residual & 20788.555 & 277 & & & \\
& Total & & & & &
\end{tabular}

Setelah melakukan uji t, diketahui bahwa ada empat variabel yang memiliki nilai $\mathrm{P}<0,05$ yaitu variabel trust informasi, struktur pengetahuan, lokus personal, dan husnudzon terhadap sesama. Maka dari itu trust informasi, struktur pengetahuan, lokus personal, dan husnudzon terhadap sesama berpengaruh signifikan terhadap kecenderungan menggunakan media sosial untuk mencari informasi. Adapun hasilnya dapat dilihat pada tabel 3 berikut: 
Tabel 3

Koefisien Regresi

\begin{tabular}{llcccc}
\hline \multirow{2}{*}{\multicolumn{1}{c}{ Model }} & \multicolumn{2}{c}{$\begin{array}{c}\text { Unstandardized } \\
\text { Coefficients }\end{array}$} & $\begin{array}{c}\text { Standardized } \\
\text { Coefficients }\end{array}$ & T & Sig. \\
\cline { 2 - 6 } & \multicolumn{2}{c}{$\begin{array}{c}\text { Std. } \\
\text { Error }\end{array}$} & Beta & & \\
\hline (Constant) & 16.971 & 6.195 & & 2.740 & .007 \\
Trust & .147 & .058 & .143 & 2.527 & $.012^{*}$ \\
Struktur Pengetahuan & .191 & .066 & .181 & 2.912 & $.004^{*}$ \\
Lokus Personal & .263 & .068 & .247 & 3.883 & $.000^{*}$ \\
Kompetensi-Keterampilan & .003 & .059 & .003 & .053 & .958 \\
Extraversion & .070 & .068 & .061 & 1.028 & .305 \\
Conscientiousness & -.129 & .084 & -.099 & -1.548 & .123 \\
Openness to Experience & -.042 & .061 & -.045 & -.690 & .491 \\
Husnudzon terhadap Allah & .014 & .064 & .015 & .220 & .826 \\
Husnudzon terhadap Sesama & .144 & .061 & .156 & 2.352 & $.019^{*}$ \\
\hline
\end{tabular}

a. Dependent Variable: Penggunaan Media Sosial

(*) Keterangan Signifikan

\section{Diskusi}

Penelitian ini berusaha untuk menjawab permasalahan yang telah dirumuskan sebelumnya, khususnya untuk mengetahui kecenderungan menggunakan media sosial untuk mencari informasi pada mahasiswa. Mengingat pentingnya peran mahasiswa sebagai ciri civitas akademika, tentu tidak lepas dari faktor internal maupun eksternal yang mempengaruhi nya. Oleh karenanya, penelitian ini dilakukan untuk melihat pengaruh internal individu yaitu trust, kepribadian HEXACO, sikap husnudzon dan faktor eksternal yaitu literasi media terhadap kecenderungan perilaku kecenderungan menggunakan media sosial untuk mencari informasi pada mahasiswa.

Berdasarkan hasil penelitian yang telah dilakukan, diketahui bahwa trust secara signifikan mempengaruhi perilaku kecenderungan menggunakan media sosial untuk mencari informasi dengan arah koefisien regresi positif. Hasil ini sejalan dengan penelitian yang dilakukan oleh Valenzuela dkk, (2009) bahwa trust memiliki pengaruh secara positif dengan perilaku kecenderungan menggunakan media sosial untuk informasi. Hal ini dikarenakan, individu yang memiliki sikap percayayang tinggi cenderung nyaman dan percaya pada salah satu aplikasi media sosial sehingga kecenderungan untuk menggunakan media sosial untuk mencari informasi lebih banyak menjadi lebih tinggi.

Faktor internal lain yang memiliki pengaruh terhadap perilaku kecenderungan menggunakan media sosial untuk mencari informasi adalah kepribadian. Berdasarkan hasil penelitian yang telah dilakukan, diketahui bahwa tipe kepribadian extraversion secara signifikan mempengaruhi perilaku kecenderungan menggunakan media sosial untuk informasi, dengan arah koefisien regresi positif. Hasil ini sejalan dengan penelitian yang dilakukan oleh Hamburger (2002), dimana extraversion 
memiliki pengaruh secara signifikan terhadap perilaku kecenderungan menggunakan media sosial untuk informasi. Hal ini dikarenakan individu dengan kepribadian extravesion aktif, mudah bergaul dan memiliki jumlah teman yang banyak, sehingga aktifitas menjadi anggota grup dan penggunaan media sosial untuk kepribadian extraversion menjadi lebih tinggi (Hamburger, 2010). Semakin individu memiliki kepribadian extravesion yang tinggi maka semakin individu akan memiliki kecenderungan-kecenderungan menggunakan media sosial untuk mencari informasi yang tinggi.

Selanjutnya, kepribadian conscientiousness diketahui tidak memiliki pengaruh secara signifikan terhadap perilaku kecenderungan menggunakan media sosial untuk informasi. Hasil ini sejalan dengan penelitian sebelumnya dimana conscientiousness tidak memiliki pengaruh secara signifikan terhadap perilaku kecenderungan menggunakan media sosial untuk informasi. Hal ini dikarenakan, individu yang memiliki kepribadian conscientiousness yang tinggi cenderung bersikap terorganisir, tekun, bekerja keras, dan bijaksana. Peneliti mengasumsikan hal tersebut dikarenakan sebagian besar mahasiswa memiliki skor conscientiousness yang rendah dimana skor tersebut menunjukkan kepribadian individu yang cenderung menunda-nunda dan tidak tepat waktu dalam mengumpulkan tugas kuliah. Hal ini didukung oleh hasil penelitian, dimana sebanyak 50,7\% dari jumlah responden didominasi oleh conscientiousness kategori rendah (Ellison dkk, 2007).

Tipe kepribadian terakhir yang tidak berpengaruh secara signifikan terhadap kecenderungan menggunakan media sosial untuk mencari informasi adalah openness to experience. Hasil ini sejalan dengan penelitian yang dilakukan oleh Sharma dan Jaswal (2015), dimana openenness to experience tidak berpengaruh pada kecenderungan menggunakan media sosial untuk informasi. Individu yang memiliki skor tinggi pada openness to experience cenderung menyukai keindahan, memiliki rasa ingin tahu yang tinggi, kreatif dan tidak konvensional pada aplikasi teknologi dan informasi dimedia sosial. Alasan yang memungkinkan openness to experience tidak berpengaruh secara signifikan dalam penelitian ini adalah karena individu dengan skor tinggi pada karakteristik kepribadianopenness to experience memiliki berbagai macam cara dalam mendapatkan informasi. Untuk memuaskan rasa keingintahuannya terhadap suatu informasi, individu dengan kepribadian openness to experience memiliki banyak cara untuk mendapatkan informasi. Alasan lainnya yang memungkinkan bahwa openness to experience tidak berpengaruh secara signifikan dalam penelitian ini adalah karena individu dengan kepribadian openness to experience tidak hanya menggunakan media sosial untuk semata-mata mencari informasi, individu tersebut juga menggunakan media sosial untuk menuangkan kreatifitas.

Selanjutnya, faktor internal lain yang memiliki pengaruh terhadap perilaku kecenderungan menggunakan media sosial untuk mencari informasi adalah sikap husnudzon. Hasil analisis menunjukkan bahwa husnudzon terhadap Allah secara positif memiliki pengaruh terhadap perilaku 
kecenderungan menggunakan media sosial untuk informasi. Artinya, semakin tinggi husnudzon terhadap Allah yang dirasakan oleh mahasiswa maka semakin tinggi perilaku kecenderungan menggunakan media sosial untuk informasi. Hal ini dikarenakan individu yang memiliki prasangka baik kepada Allah, maka akan semakin cenderung untuk menggunakan media sosial untuk mencari informasi tentang Allah lebih banyak.Padahasil analisis sikap husnudzon terhadap sesama menunjukkan bahwa husnudzon terhadap sesama secara positif memiliki pengaruh terhadap perilaku kecenderungan menggunakan media sosial untuk informasi. Artinya, semakin tinggi husnudzon terhadap sesama yang dirasakan oleh mahasiswa maka semakin tinggi perilaku kecenderungan menggunakan media sosial untuk informasi. Hasil ini sejalan dengan penelitian sebelumnya bahwa husnudzon terhadap sesamamemiliki pengaruh secara positifterhadap perilaku kecenderungan menggunakan media sosial untuk informasi. Semakin individu cenderung berprasangka baik, maka semakin individu tersebut menggunakan media sosial untuk informasi dengan konten positif dan tidak diskriminatif. Sebaliknya, semakin individu dengan frekuensi pencarian informasi rendah di media sosial, maka semakin individu tersebut cenderung menunjukkan sikap prasangka buruk dan pola diskriminasi (Rauch dkk, 2013)

Selain trust, kepribadian, dan husnudzon perilaku kecenderungan menggunakan media sosial untuk mencari informasi juga dapat dipengaruhi oleh faktor eksternal seperti literasi media. Hasil analisis menunjukkan bahwa terdapat dua dimensi pada literasi media yang memiliki pengaruh secara signifikan terhadap perilaku penggunaaan media sosial untuk informasi, yaitu struktur pengetahuan dan lokus personal. struktur pengetahuan dan lokus personal diketahui memiliki pengaruh secara signifikan dengan arah koefisien regresi positif. Artinya, semakin tinggi struktur pengetahuan dan lokus personal pada mahasiswa maka semakin tinggi perilaku penggunaaan media sosial untuk informasi.

Hasil temuan ini sejalan dengan penelitian yang dilakukan oleh Wegmann (2015) dimana struktur pengetahuan dan lokus personal memiliki pengaruh terhadap perilaku penggunaaan media sosial untuk informasi. Selain itu, penelitian yang dilakukan oleh Leung and Lee (2012) juga memperkuat temuan ini dimana lokus personal dan struktur pengetahuan dapat mengurangi kecenderungan penggunaan media sosial secara negatif, individu akan lebih menggunakan media sosial untuk mencari informasi. Semakin individu memiliki struktur pengetahuan dan dapat mengontrol diri atau memiliki lokus personal yang baik, maka semakin individu tersebut menggunakan media sosial untuk mencari informasi yang benar.

Ditemukan hasil beberapa variabel yang tidak berpengaruh. Variabel yang tidak berpengaruh dapat dikarenakan adanya keterbatasan yang terjadi dalam proses penelitian, seperti keterbatasan waktu responden dalam mengisi kuesioner, adanya responden yang tidak bersedia merespon 
jawaban pada skala tertentu, maupun kurangnya variasi dari sampel. Hal inilah yang memungkinkan satu dimensi mempengaruhi dimensi lain sehingga diperoleh hasil yang tidak signifikan.

\section{Daftar pustaka}

Ashton, M. C., \& Lee, K. (2007). Empirical, theoretical, and practical advantages of the HEXACO model of personality structure. Personality and social psychology review, 11(2), 150-166.

Berlo, D. K., Lemert, J. B., \& Mertz, R. J. (1969). Dimensions for evaluating the acceptability of message sources. Public opinion quarterly, 33(4), 563-576.

Dhont, K., \& Van Hiel, A. (2011). Direct contact and authoritarianism as moderators between extended contact and reduced prejudice: Lower threat and greater trust as mediators. Group Processes \& Intergroup Relations, 14(2), 223-237.

Ellison, N. B., Steinfield, C., \& Lampe, C. (2007). The benefits of Facebook "friends:" Social capital and college students' use of online social network sites. Journal of computermediated communication, 12(4), 1143-1168.

Fajar, M. A., \& Lutfi, I. (2017). Pengaruh trait kepribadian (personality) dan dukungan sosial terhadap risk taking behavior pada pendaki gunung.

Hamburger, Y. (2002). Internet and personality. Computers in Human Behavior, 18(1), 1-10.

Hamburger, A., Meil, A., Trehin, A., ...\& Jacq, B. (2005). Protein interaction mapping: a Drosophila case study. Genome research, 15(3), 376-384.

Hamburger, Y., \& Vinitzky, G. (2010). Social network use and personality. Computers in human behavior, 26(6), 1289-1295.

Idcloudhost (2016). Mengenal Apa itu Phising, Penyebab, dan Mengatasinya. Diperoleh 12 September 2018, dari https://idcloudhost.com/mengenal-apa-itu-phising-penyebab-danmengatasinya/

Jung, N., Kim, Y., \& De Zúniga, H. G. (2011). The mediating role of knowledge and efficacy in the effects of communication on political participation. Mass Communication and Society, 14(4), 407-430. 
Katz, E., Blumler, J. G., \& Gurevitch, M. (1974). Utilization of mass communication by the individual. In Jay G Blumler \& E. Katz (Eds.), The uses of mass communications: Current perspectives on gratifications research (Vol. 3) (pp. 19-32). Beverly Hills, CA: Sage.

Kompas (2017).Mengapa Banyak Orang Mudah Percaya Berita "Hoax"?. Diperoleh 12 September 2018 , dari https://nasional.kompas.com/read/2017/01/23/18181951/mengapa.banyak.orang.mudah.perc aya.berita.hoax.

Kompas (2018). Kronologi Drama Kebohongan Ratna Sarumpaet. Diperoleh 22 Juli 2019, dari https://nasional.kompas.com/read/2018/10/04/09114291/kronologi-drama-kebohongan$\underline{\text { ratna-sarumpaet?page }=\text { all }}$

Kompas (2018). 87 Tahun Jakob Oetama dan Era Banjir Informasi. Diperoleh 8 Agustus 2019, dari https://nasional.kompas.com/read/2018/09/27/06085651/87-tahun-jakob-oetama-danera-banjir-informasi?page $=1$

Lee, K., \& Ashton, M. C. (2004). Psychometric properties of the HEXACO personality inventory. Multivariate behavioral research, 39(2), 329-358.

Lee, K., Ashton, M. C., Wiltshire, J., Bourdage, J. S., Visser, B. A., \& Gallucci, A. (2013). Sex, power, and money: Prediction from the Dark Triad and Honesty-Humility. European Journal of Personality, 27(2), 169-184.

Leung, L., \& Lee, P. S. (2012). The influences of information literacy, internet addiction and parenting styles on internet risks. New Media \& Society, 14(1), 117-136.

Mahardika, Y. R. C. (2017). Perilaku Mahasiswa Dalam Menyikapi Pemberitaan Hoax Di Media Sosial Facebook. Studi pada Mahasiswa Ilmu Komunikasi Universitas Muhammadiyah Malang Angkatan 2013 yang Menerima Pemberitaan Hoax Terkait Isu Corporate Nasional. (Doctoral dissertation, University of Muhammadiyah Malang).

McKnight, D. H., Choudhury, V., \& Kacmar, C. (2002). Developing and validating trust measures for e-commerce: An integrative typology. Information systems research, 13(3), 334-359.

Maksl, A., Ashley, S., \& Craft, S. (2015). Measuring news media literacy. Journal of Media Literacy Education, 6(3), 29-45. 
Mutz, D. C. (1998). Impersonal influence: How perceptions of mass collectives affect political attitudes. Cambridge University Press.

Pepitone, J (2010). Twitter users not so social after all. CNNMoney.com. Diperoleh 14 Maret 2010, dari http://money.cnn.com/2010/03/10/technology/twitter_users_active/index. htm?hpt=Mid

Potter, W. J. (2004). Theory of media literacy: A cognitive approach. Sage Publications.

Rauch, S. M., \& Schanz, K. (2013). Advancing racism with Facebook: Frequency and purpose of Facebook use and the acceptance of prejudiced and egalitarian messages. Computers in Human Behavior, 29(3), 610-615.

Rusydi, A. (2012). Husn Al-Zhann: Konsep berpikir positif dalam perspektif psikologi islam dan manfaatnya bagi kesehatan mental. Disertasi, Jakarta: Universitas Islam Negeri Syarif Hidayatullah.

Sharma, A., \& Jaswal, I. (2015). Personality and Patterns of Facebook Usage.

Susanto, E. H. (2017). Media sosial sebagai pendukung jaringan komunikasi politik. Jurnal Aspikom, 3(3), 379-398.

Tirto.id (2017).Literasi Rendah Sebabkan Masyarakat Mudah Percaya Hoax. Diperoleh 12 September 2018, dari https://tirto.id/literasi-rendah-sebabkan-masyarakat-mudah-percayahoax-cnQa

Tirto.id (2018). Deretan Hoaks Ratna Sarumpaet dan Ancaman Pidana yang Memburunya. Diperoleh 22 Juli 2019, dari https://tirto.id/deretan-hoaks-ratna-sarumpaet-dan-ancamanpidana-yang-memburunya-c4xp

Tirto (2019). Kemenag Bantah Tudingan Mahfud MD Soal Pemilihan Rektor UIN Jakarta. Diperoleh 17 Juli 2019, dari https://tirto.id/kemenag-bantah-tudingan-mahfud-md-soalpemilihan-rektor-uin-jakarta-djZk

Tsfati, Y., \& Capella, J. N. (2003). Do people watch what they do not trust? Exploring the association between news media skepticism and exposure. Communication Research, 30(5), 504-529.

Vraga, E. K., Tully, M., \& Rojas, H. (2009). Media literacy training reduces perception of bias. Newspaper Research Journal, 30(4), 68-81. 
Vries, R. E. (2013). The 24-item brief HEXACO inventory (BHI). Journal of Research in Personality, 47(6), 871-880.

Wegmann, E., Stodt, B., \& Brand, M. (2015). Addictive use of social networking sites can be explained by the interaction of Internet use expectancies, Internet literacy, and psychopathological symptoms. Journal of behavioral addictions, 4(3), 155-162.

Westerman, D., Spence, P. R., \& Van Der Heide, B. (2013). Social media as information source: Recency of updates and credibility of information. Journal of computer-mediated communication, 19(2), 171-183.

Winkelmann, S. (2012). The Social Media (R) evolution. Asian Perspectives on New Media. Singapore: Konrad Adenauer-Stiftung.

Zúñiga, H., \& Valenzuela, S. (2011). The mediating path to a stronger citizenship: Online and offline networks, weak ties, and civic engagement. Communication Research, 38(3), 397421.

Zúñiga, H., Jung, N., \& Valenzuela, S. (2012). Social media use for news and individuals' social capital, civic engagement and political participation. Journal of computer-mediated communication, 17(3), 319-336. 